九州大学学術情報リポジトリ

Kyushu University Institutional Repository

\title{
Change of Color and Wettability of Heat-treated Hard Maple Lumber
}

KANG, Chun-Won

Department of Housing Environmental Design, and Research Institute of Human Ecology, College of Human Ecology, Chonbuk National University

KANG, Ho-Yang

Department of Bio-based Materials, Chungnam National University

MATSUMURA, Junj $\mathrm{i}$

Laboratory of Wood Science, Division of Sustainable Bioresources Science, Faculty of Agriculture, Kyushu University

https://doi. org/10.5109/2232294

出版情報：九州大学大学院農学研究院紀要. 64 (1)，pp.113-117，2019-02-28. Faculty of Agriculture, Kyushu University

バージョン :

権利関係 : 


\title{
Change of Color and Wettability of Heat-treated Hard Maple Lumber
}

\author{
Chun-Won KANG ${ }^{1}$, Ho-Yang KANG ${ }^{* 2}$ and Junji MATSUMURA \\ Laboratory of Wood Science, Division of Sustainable Bioresources Science, \\ Faculty of Agriculture, Kyushu University, Fukuoka 819-0395, Japan \\ (Received October 31, 2018 and accepted November 12, 2018)
}

\begin{abstract}
In order to investigate change of wood color and wettability of hard maple after heated at the temperature of $165^{\circ} \mathrm{C}, 180^{\circ} \mathrm{C}$ and $195^{\circ} \mathrm{C}, \mathrm{L}^{*} \mathrm{a}^{*} \mathrm{~b} *$ was measured using a color-difference meter, the anti-absorption efficiency, anti-swelling efficiency and anti-volume efficiency of specimens were calculated in this study. The results of this study were as followings: Chrominance was lowest (17.5) for $165^{\circ} \mathrm{C}$ and highest (43.5) for $195^{\circ} \mathrm{C}$ treated specimen. As heat temperature was increasing, the whiteness index and yellowness index of the surface layer of treated specimens were reduced but redness index was increased while the whiteness index of the inner layer of specimens presented higher value, however, the yellowness index and redness index presented lower value compared to surface layer of specimens.

Anti-absorption efficiency and anti-swelling efficiency of treated specimens were significantly increased as heat temperature being increasing. Anti-absorption efficiency was high when specimens were subjects to high temperature and low relative humidity and that was low when specimens were subjects to low temperature and high relative humidity.
\end{abstract}

Key words: Heat treatment, Color change, Anti-Absorption Efficiency, Anti-Swelling Efficiency, AntiVolume Efficiency

\section{INTRODUCTION}

Hard maple was widely used as high quality wood products such as gym floor, stairs, bowling pins, Piano action etc. because of its brilliant wood color and hard texture, however, when it was applied to high quality interior, coloring was necessary. Artificial coloring with stain was not only eco-friendly and unnatural. Recently technology of eco-friendly and natural concentrate by heating treatment was developed (Chen et al., 2012; Matsuo et al., 2016). Heating treatment was not only concentrate wood color but also increase the dimensional stability and weather resistance (Borrega and Kaerenlampi, 2010; Korkut et al., 2010; Poncsak et al., 2011). The wood color was changed into more uniform from surface to inside wood after heat treatment than before heat treatment.

The effect of heat treatment on the color and wettability of the maple lumbers was investigated in this study.

\section{MATERIALS AND METHODS}

\section{Specimen Preparation}

8 pieces of kiln dried hard maple (Acer saccharum) lumbers with the dimension of $28 \mathrm{~mm}$ in thickness, $145 \mathrm{~mm}$ in width and $800 \mathrm{~mm}$ in length were prepared for four treatments. The moisture contents of specimens were $9.5-11.0 \%$, measured with portable dielectric

\footnotetext{
Department of Housing Environmental Design, and Research Institute of Human Ecology, College of Human Ecology, Chonbuk National University, Jeonju 54896, Korea

${ }^{2}$ Department of Bio-based Materials, Chungnam National University, Daejeon 34134, Korea

* Corresponding author (E-mail: hykang@cnu.ac.kr)
}

constant-type moisture meter (HM530, KETT).

\section{Heating treatment}

The treatment had been conducted in a kiln that had the stack space of $700 \mathrm{~mm}$ in width and $600 \mathrm{~mm}$ in height and $800 \mathrm{~mm}$ in length. The thickness of stacker was $20 \mathrm{~mm}$. The air velocity was $4 \mathrm{~m} / \mathrm{s}$. The schedule for heat treatment was shown in Figure 1. During drying stage, the time to rise temperature was 1 hour from start to $100^{\circ} \mathrm{C}$, at which remained 10 hours. During heat treatment, the temperature had been risen for 10 hours until reaching target temperature and remaining it 3 hours, then cooled dawn which needed 10 hours. The control specimens had dried at $100^{\circ} \mathrm{C}$ for 2 days.

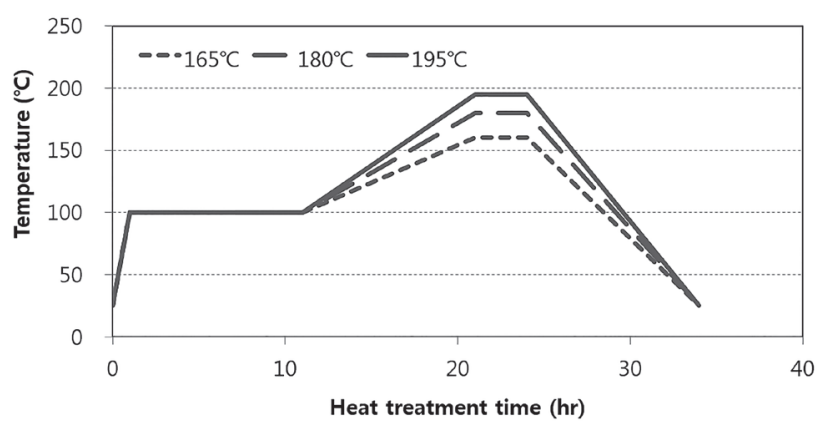

Fig. 1. Three different schedules for heat treatment.

\section{Measuring wood color}

CIE $\mathrm{L}^{*} \mathrm{a} * \mathrm{~b} *$ were measured using a color-difference meter (Hunter Lab Mini Scan XE Plus). A source of light was Xenon flash lamp in the wavelength range of $400 \sim 700 \mathrm{~nm}$. At three positions on each surface of specimens before and after the specimens were planned to $22.5 \mathrm{~mm}$ of thickness, the wood color was measured. Average values measured from six positions were used 
as chrominance $\left(\Delta \mathrm{E}^{*}\right), \Delta \mathrm{E}^{*}$ was calculated by the equation [1].

$$
\Delta \mathrm{E}^{*}=\sqrt{\left(\mathrm{L}_{2}^{*}-\mathrm{L}_{1}^{*}\right)^{2}+\left(\mathrm{a}_{2}^{*}-\mathrm{a}_{1}^{*}\right)^{2}+\left(\mathrm{b}_{2}^{*}-\mathrm{b}_{1}^{*}\right)^{2}} .
$$

Here, $\Delta \mathrm{E}^{*}$ was chrominance, $\mathrm{L}^{*}$ was whiteness index, $\mathrm{a}^{*}$ was redness index, $b^{*}$ was yellowness index

\section{Specimens to measure moisture content}

After measuring wood color, eight pieces of samples, six pieces for sorption test and two pieces for water absorption test, were cut at the central part of the specimens with length of $800 \mathrm{~mm}$.

\section{Water absorption test}

The weights and dimensions of specimens were measured before and after being impregnated in distilled water for five days, and then Anti-Absorption Efficiency (Eab) and Anti-Swelling Efficiency (Esw) were calculated from the equation [2], [3] and [4].

$$
\begin{aligned}
& E_{a b}=\alpha_{c}-\alpha_{h} \\
& \alpha=\frac{W_{f}-W_{o d}}{W_{o d}} \times 100 \%
\end{aligned}
$$

Here, $E_{a b}=$ anti-absorption efficiency (\%), $\alpha_{c}=$ weight percent gain of control specimen (\%), $\alpha_{h}=$ weight percent gain of treated specimen (\%), $W_{\text {od }}=$ oven-dry weight (g), $W_{f}=$ weight after impregnation (g)

$$
\begin{aligned}
& E_{s w-l}=\beta_{c}-\beta_{h} \\
& \beta=\frac{L_{f}-L_{o d}}{L_{o d}} \times 100 \%
\end{aligned}
$$

Here, $E_{s w-l}=$ anti-swelling efficiency (\%), $\beta_{\mathrm{c}}=$ length growth rate of control specimen (\%), $\beta_{h}=$ length growth rate of treated specimen (\%), $L_{o d}=$ oven-dry length $(\mathrm{cm}), L_{f}=$ catcher's length $(\mathrm{cm})$

$$
\begin{aligned}
& E_{s w-v}=\chi_{c}-\chi_{h} \\
& \chi=\frac{V_{f}-V_{o d}}{V_{o d}} \times 100 \%
\end{aligned}
$$

Here, $E_{s w-v}=$ anti-volume efficiency (\%), $\gamma_{c}=$ volume growth rate of control specimen (\%), $\gamma_{h}=$ volume growth rate of treated specimen (\%), $V_{\text {od }}=$ oven-dry volume $\left(\mathrm{cm}^{3}\right), V_{f}=$ catcher's volume $\left(\mathrm{cm}^{3}\right)$

\section{Saturated salt solution experiment}

Different kinds of saturated salt solution were made in six desiccators. Relative humidity inside desiccator was different according to the different saturated salt solution as shown in Table 1. After six specimens were put in different desiccator, the cover of desiccator was closed and the edge of cover was sealed with vaseline. After the balance of specimens was reached, the weight of specimens was measured, and specimens were oven dried and weighted.
Table 1. Relative humidities (RHs) of saturated salt solutions used for this experiment (Hoadley, 2000)

\begin{tabular}{cc}
\hline Saturated salt solution & $\mathrm{RH}(\%)$ at $20^{\circ} \mathrm{C}$ \\
\hline $\mathrm{CaCl}_{2} \cdot 2 \mathrm{H}_{2} \mathrm{O}$ & 32.0 \\
$\mathrm{NaBr}$ & 58.0 \\
$\left(\mathrm{NH}_{4}\right)_{2} \mathrm{SO}_{4}$ & 80.5 \\
$\mathrm{ZnSO}_{4} \cdot 7 \mathrm{H}_{2} \mathrm{O}$ & 90.0 \\
$\mathrm{NaSO}_{4}$ & 95.0 \\
$\mathrm{H}_{2} \mathrm{O}$ & 100.0 \\
\hline
\end{tabular}

Equilibrium Moisture Content (EMC) of specimen was calculated from equation [5].

$$
E M C=\frac{W_{e q}-W_{o d}}{W_{o d}} \times 100 \%
$$

Here, $E M C$ = equilibrium moisture content (\%), $W_{e q}=$ weight after absorption (g), $W_{\text {od }}=$ oven dry weight (g) $\mathrm{E}_{\mathrm{ad}}$ was calculated from equation [6].

$$
\Delta E_{a d}=\frac{E M C_{c n}-E M C_{h t}}{E M C_{c n}} \times 100 \% \times 100 \%
$$

Here, $E_{a d}=$ anti-adsorption efficiency (\%), $E M C_{c n}=$ EMC of control specimen (\%), $E M C_{h t}=\mathrm{EMC}$ of treated specimen $(\%)$

\section{RESULTS AND DISCUSSION}

\section{Oven-dry density}

The oven-dry densities of specimens are shown in Table 2. The oven-dry densities of treated specimens were $0.693 \mathrm{~g} / \mathrm{cm}^{3}, 0.691 \mathrm{~g} / \mathrm{cm}^{3}$, and $0.690 \mathrm{~g} / \mathrm{cm}^{3}$, showed a trend of the density being reduced as the temperature being increased. It was found that there was a highly significant difference between treated and control specimens but there was not significant difference between treated specimens.

Table 2. Comparison between the oven-dry densities of heattreated and control specimens

\begin{tabular}{ccc}
\hline \multirow{2}{*}{ Specimen } & \multicolumn{2}{c}{ Oven-dry density $\left(\mathrm{g} / \mathrm{cm}^{3}\right)$} \\
\cline { 2 - 3 } & Average & Standard deviation \\
\hline Con & 0.712 & 0.002 \\
$165^{\circ} \mathrm{C}$ & 0.693 & 0.004 \\
$180^{\circ} \mathrm{C}$ & 0.691 & 0.007 \\
$195^{\circ} \mathrm{C}$ & 0.690 & 0.006 \\
\hline
\end{tabular}

\section{Comparison of wood color between surface and inner layer}

The wood color of treated and control specimens before being planned is presented as shown in Table 2 . The wood color of treated specimens was deeper than that of control specimens, and deeper as the temperature of heat being increased. The results of wood color measured before and after the specimens were planned 


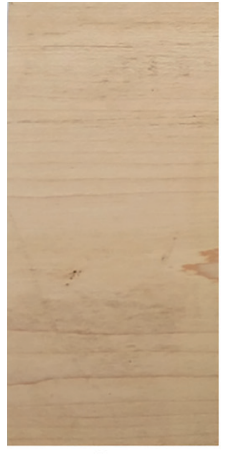

Con

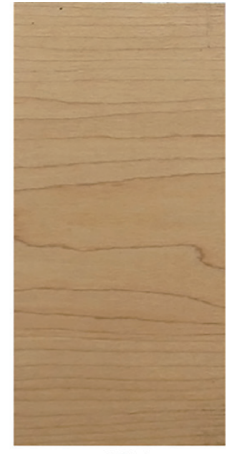

$165^{\circ} \mathrm{C}$

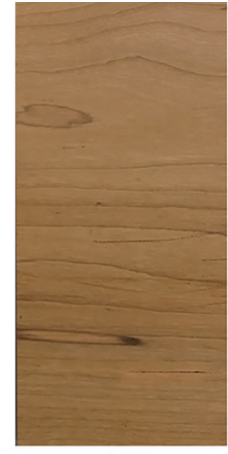

$180^{\circ} \mathrm{C}$

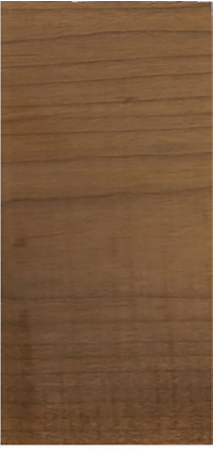

$195^{\circ} \mathrm{C}$

Fig. 2. Photos of heat-treated at three different temperatures and control specimens.

are displayed in Figure 3. As heat temperature was increasing, the whiteness index and yellowness index of treated specimens were reduced but the redness index was increased. Whiteness index of inner layer of the inner layer of specimens presented higher value than that of the surface layer while the yellowness index and redness index presented lower value compared to surface layer of specimens. The difference in chrominance before and after the specimens were planned was biggest for control specimens, this could be accounted for less thermal degradation of control specimen under the temperature of $103^{\circ} \mathrm{C}$ than that of treated specimens under the temperature of $165^{\circ} \mathrm{C}$

\section{Chrominance}

Chrominance $\left(\Delta \mathrm{E}^{*}\right)$ of other specimens except control specimen was calculated from equation [1] by the standard of wood color of control specimen because change of wood color of which was least (Figure 4). Chrominance was lowest (17.5) for $165^{\circ} \mathrm{C}$ treated specimen, highest (43.5) for $195^{\circ} \mathrm{C}$ treated specimen. Chrominance of specimens presented significant differences compared to that of inner layer of control specimen. There was no large difference between surface layer and inner layer of treated specimens, and the difference become smaller as heat temperature being increasing.

\section{Anti-absorption efficiency}

Absorption graph of specimens is shown in Figure 5. The moisture contents of all specimens were sharply increased until six hours after impregnation, and become gentle. The absorption rate was highest for control specimens, and lower as heat temperature being increasing. After 15 hours of impregnation, Eab was 0\% for $165^{\circ} \mathrm{C}$ treated specimen, $6.9 \%$ for $180^{\circ} \mathrm{C}$ treated specimen and $21.7 \%$ for $195^{\circ} \mathrm{C}$ treated specimen, which indicated that anti-absorption efficiency was significantly increased as heat temperature being increasing.

\section{Anti-swelling efficiency}

$\mathrm{E}_{\mathrm{sw}-1}$ and $\mathrm{E}_{\mathrm{sw}-\mathrm{v}}$ are shown in Figure 6. $\mathrm{E}_{\mathrm{sw}-1}$ was larger in width than in thickness. $\mathrm{E}_{\mathrm{sw}-1}$ and $\mathrm{E}_{\mathrm{sw}-\mathrm{v}}$ were increased as heat temperature being increasing. $\mathrm{E}_{\mathrm{sW}-\mathrm{v}}$ was very low
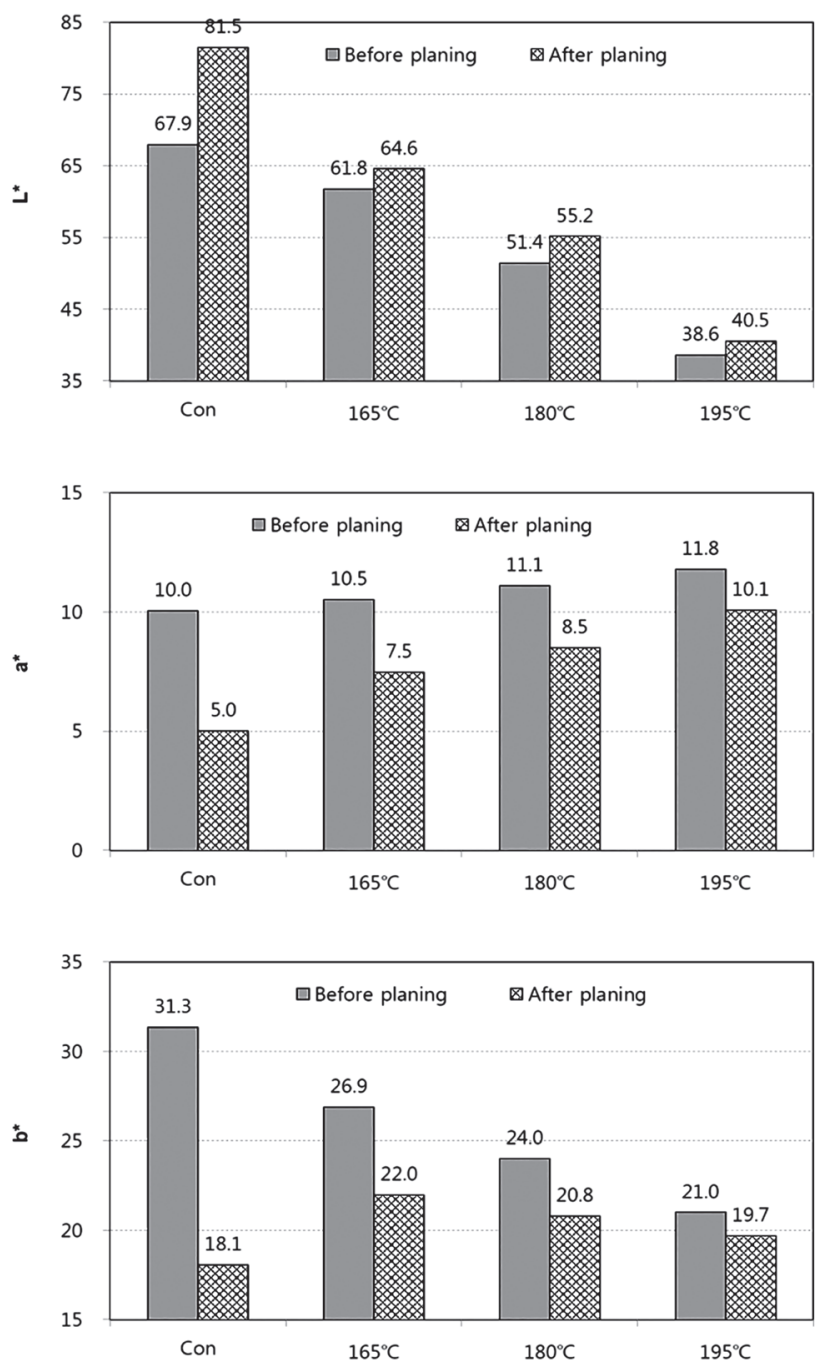

Fig. 3. Color indexes measured before and after planning of control and heat- treated specimens.

(0.9\%) for $165^{\circ} \mathrm{C}$ treated specimen while $\mathrm{E}_{\mathrm{sw}-\mathrm{v}}$ was high $(6.6 \%)$ for $19^{\circ} \mathrm{C}$ treated specimen.

\section{Sorption isotherm curve and anti-absorption effi- ciency}

Sorption isotherm curve obtained from saturated 


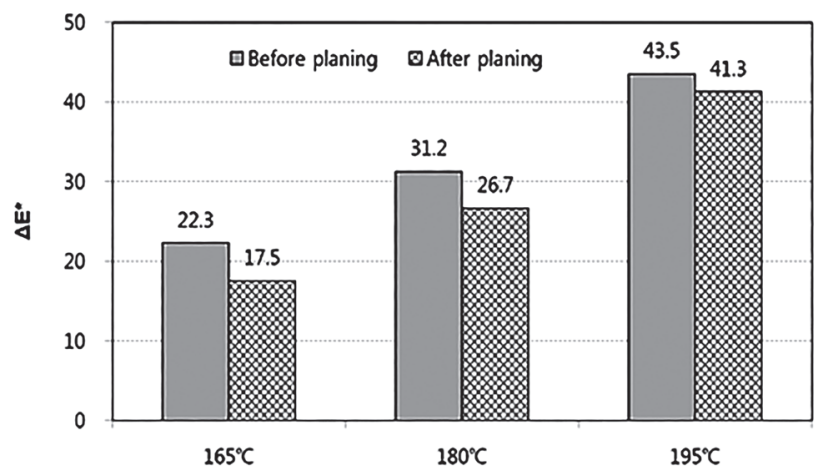

Fig. 4. Color differences $\left(\Delta \mathrm{E}^{*}\right)$ before and after planning of heattreated specimens compared to the color of the control specimen.

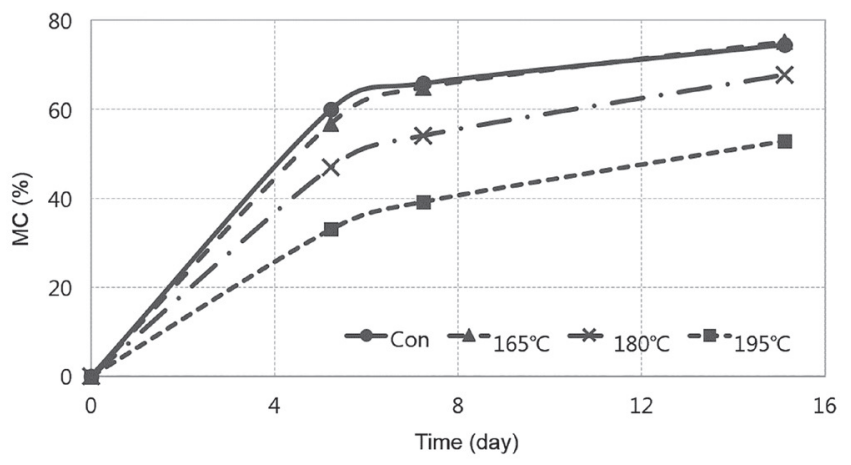

Fig. 5. Moisture content curves of specimens soaked in water.

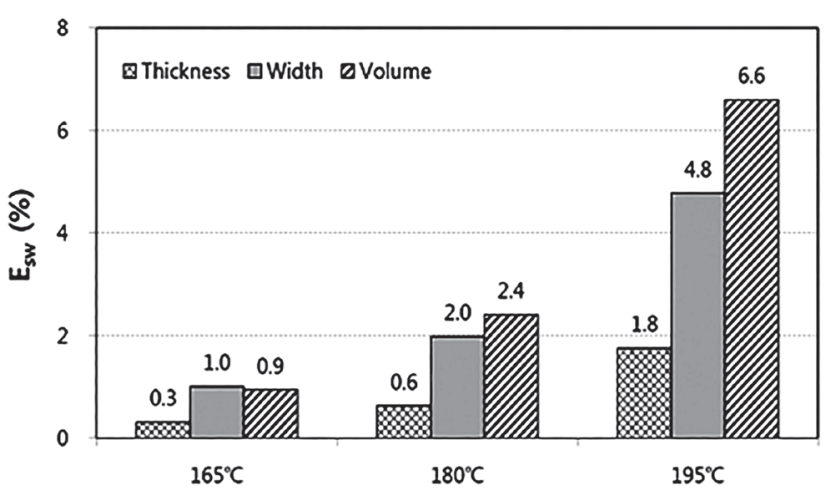

Fig. 6. Anti-swelling efficiencies of heat- treated specimens.

salt solution experiment is shown in Figure 7. The curve of control specimen was at position of highest while that of treated specimens was at lower position, which indicates that EMC was lower as heat temperature of treated specimens being increased. $\mathrm{E}_{\mathrm{ad}}$ is shown in Table 3. Anti-absorption efficiency was increasing as heat temperature of treated specimens being increased under same relative humidity, which means that adsorption points was reduced as heat temperature of treated specimens being increased. Meanwhile, there was a trend of $\mathrm{E}_{\mathrm{ad}}$ being reduced when relative humidity was increased. $\mathrm{E}_{\text {ad }}$ of $195^{\circ} \mathrm{C}$ treated specimens was highest as being $46.8 \%$ under the lowest relative humidity of $32.0 \%$ while that of $165^{\circ} \mathrm{C}$ treated specimens was lowest as being

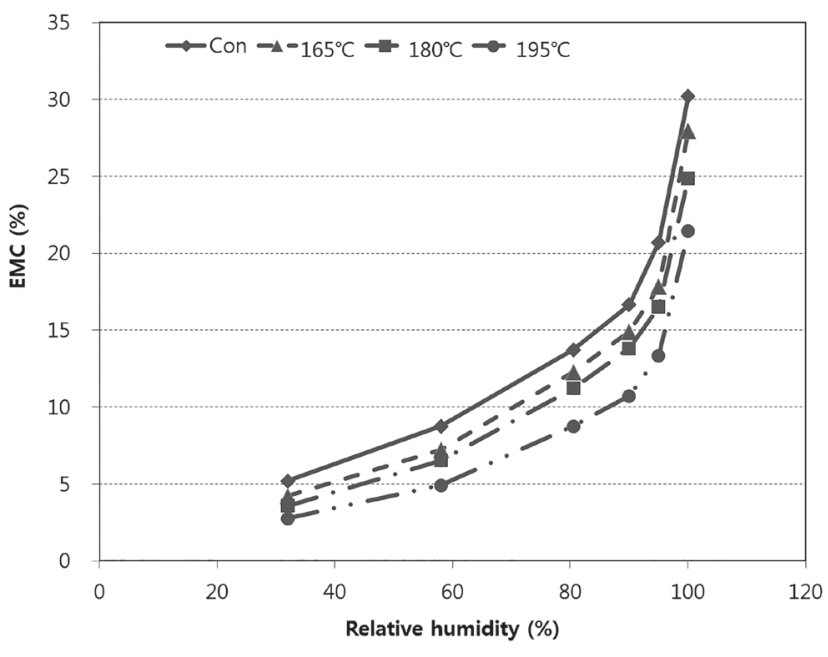

Fig. 7. Sorption isotherm curves of the specimens heat- treated at $165,180^{\circ} \mathrm{C}$ and $195^{\circ} \mathrm{C}$, compared with the control.

Table 3. Anti- Adsorption Efficiency $\left(\mathrm{E}_{\mathrm{ad}}\right.$ ) of heat- treated specimens at various $\mathrm{RH}$

\begin{tabular}{cccc}
\hline \multirow{2}{*}{$\mathrm{RH}(\%)$} & \multicolumn{3}{c}{ Temperature of heat treatment } \\
\cline { 2 - 4 } & $165^{\circ} \mathrm{C}$ & $180^{\circ} \mathrm{C}$ & $195^{\circ} \mathrm{C}$ \\
\hline 32.0 & 18.9 & 31.1 & 46.8 \\
58.0 & 17.8 & 25.5 & 44.1 \\
80.5 & 10.5 & 18.2 & 36.2 \\
90.0 & 10.6 & 17.0 & 35.6 \\
95.0 & 13.8 & 20.2 & 35.5 \\
100.0 & 7.5 & 17.6 & 29.0 \\
\hline
\end{tabular}

7.5\% under the highest relative humidity of $100 \%$. It was noted that anti-absorption efficiency was high when specimens were subjects to high temperature and low relative humidity and that was low when specimens were subjects to low temperature and high relative humidity.

\section{CONCLUSIONS}

In order to investigate change of wood color and wettability of Canadian hard maple after high temperature heated treatment, L*a*b* was measured using a color-difference meter, Anti-absorption efficiency, antiswelling efficiency and anti-volume efficiency of specimens were calculated. The results of this study were as followings:

1. Chrominance was lowest (17.5) for $165^{\circ} \mathrm{C}$ treated specimen and highest (43.5) for $195^{\circ} \mathrm{C}$ treated specimen, presented significant differences compared to that of inner layer of control specimen. As heat temperature was increasing, the whiteness index and yellowness index of the surface layer of treated specimens were reduced but redness index was increased while the whiteness index of the inner layer of specimens presented higher value, however, the yellowness index and redness index presented lower value 
compared to surface layer of specimens.

2. Anti-absorption efficiency and anti-swelling efficiency of treated specimens were significantly increased as heat temperature being increasing

3. Anti-absorption efficiency was high when specimens were subjects to high temperature and low relative humidity and that was low when specimens were subjects to low temperature and high relative humidity.

\section{ACKNOWLEDGMENTS}

This study was carried out with the support of R\&D Program for Forest Science Technology (Project No. 2014068D10-1719-AA03) provided by Korea Forest Service (Korea Forestry Promotion Institute).

\section{REFERENCES}

Borrega, M., P. Karenlampi 2010 Hygroscopicity of heat-treated Norway spruce (Picea abies) wood. Holz als Roh-und Werkstoff. $\mathbf{6 8}(2)$ : 233-235

Chen, Y., Y. Fan., J. Gao., M. Tshabalala and N. Stark 2012 Spectroscopic analysis of the role of extractives on heatinduced discoloration of black locust (Robinia pseudoacacia). Wood Material Science \& Engineering. 7(4): 209-216

Esteves, B., I. Domingoes and H. Pereira 2007 Improvement of technological quality of eucalypt wood by heat treatment in air at $170-200^{\circ} \mathrm{C}$. Forest Products Journal. 57 (1/2): 47-52

Esteves, B, I. Domingoes and H. Pereira 2008 Heat treatment of pine wood. Bio Resources. 3(1): 142-154

Forest Products Laboratory. 2010. Wood Handbook. General Technical Report FPL-GTR-190. Madison, Wi, USA

Hoadley, R. 2000 Understanding Wood. The Taunton Press,
Inc., CT, USA, pp.288

Huang, R., J. Lu and Y. Zhan 2011 Relationship between CIE $\mathrm{L}^{*} \mathrm{a} \mathrm{b}^{*}$ and Wood Properties of Heat-treated Blue-Stained Lodgepole Pine (Pinus contorta) Timber. Mokuzai Gakkaishi. 57(5): 276-282

Korkut, S., S. Karayilmazlar., S. Hiziroglu and T. Sanli 2010 Some of the Properties of Heat-Treated Sessile Oak (Quercus petraea). Forest Products Journal. 60(5): 473-480

Lekounougou, S., D. Kocaefe 2012. Comparative study on the durability of heat-treated White Birch (Betula papyrifera) subjected to the attack of brown and white rot fungi. Wood Material Science \& Engineering. 7(2): 101-106

Matsuo, M., K. Umemura and S. Kawai 2012 Kinetic analysis of color changes in cellulose during heat treatment. Journal of Wood Science. 58(2): 113-119

Matsuo, Mi., K. Mitsui and I. Kobayashi 2016 Effect of hygrothermal treatment on wood properties: color changes and kinetic analysis using four softwood and seven hardwood species. Wood Science and Technology. 50(6): 1145-1160

Mohareb, A., P. Sirmah 2012 Effect of heat treatment intensity on wood chemical composition and decay durability of Pinus patula. Eur. J. Wood Prod. 70(4): 519-524

Poncsak, S., D. Kocaefe and R. Younsi 2011 Improvement of the heat treatment of Jack pine (Pinus banksiana) using ThermoWood technology. Holz als Roh-und Werkstoff. 69(2): 281-286

Tejada, A., T. Okuyama., H. Yamamoto and M. Yoshida 1997 Reduction of growth stress in logs by direct heat treatment: Assessment of a commercial-scale operation. Forest Products Journal. 47(9): 86-93

Yao, C., F. Yongming., G. Jianmin and L. Houkun 2012 Coloring characteristics of in situ lignin during heat treatment. Wood Science and Technology. 46(1-3): 33-40

Yinodotlgoer, N., N. Kartal 2010 Heat Modification of Wood: Chemical Properties and Resistance to Mold and Decay Fungi. Forest Products Journal. 60(4): 357-361 